\title{
EUROPEAN UNION FRAMEWORK FOR FORESTRY SUPPORT AND ITS IMPLEMENTATION IN LATVIA
}

\begin{abstract}
Raimonds BERMANIS, Faculty of Forestry, Latvia Agriculture University, Address: Liela iela 2, Jelgava, Latvia; raimonds.bermanis@mkpc.llkc.lv (coresponding author)

Inga STRAUPE, Faculty of Forestry, Latvia Agriculture University, Address: Liela iela 2, Jelgava, Latvia, inga.straupe@1lu.lv Andra ZVIRBULE, Faculty of Economics and Social Development, Latvia Agriculture University, Address: Liela iela 2, Jelgava, Latvia; andra.zvirbule@1lu.lv

The Paper covers an analysis of most significant European Union (EU) legal acts regulating financial support granted for private forestry over the period of 2014-2020, coherence to support measures implemented in Latvia for a certain period. The review consists of two main legal acts from the EU - Forest Strategy for forests and the forest-based sector and the EU regulation No. 1305/2013 of the European Parliament and the Council on support for rural development by the European Agriculture Fund for Rural development, while from the national perspective, the review was prepared for Latvia's Rural development programme (NRDP) for the period 20142020 and national regulations issued by the Cabinet of Ministers of the Republic of Latvia. The paper focuses on the support measures intended to foster and develop forestry sector, evaluating priorities and expected results laid down in the EU documents, versus measures implemented in Latvia through the NRDP 2014-2020, related to national regulations and rules of the responsible state authorities. The analysis contains several groups of measures applicable for private forestry: 1) Information, advice, knowledge and efficiency; 2) Forestry activities; 3 ) Investments in forestry; 4) Nature care. Not all the measures which may be introduced according to the EU regulations No. 1305/2013 were implemented for private forestry support in Latvia, also several in the NRDP 2014-2020 affordable measures were not introduced practically till November 2017, but regarding those which have already been implemented, their impact on forestry development should be further estimated.
\end{abstract}

Keywords: EU funds, private forestry, financial suppor for forestry.

\section{INTRODUCTION}

Forest area in Latvia covers 3.383 million ha, $52 \%$ of total state land area. Private forests owned by physical and legal persons compose $50 \%$ of the total forest area. Forest properties are fragmented and forest estates of less than 50 ha cover $60.7 \%$ from the total private forest area. The total number of private forest owners is 136,966 , (data for the year 2015), and their number continues to decline. In recent 20 years the percentage of forests has grown by $2.6 \%$, as a result of natural afforestation process and artificial creation of woodland. (LFRI Silava, State Land service information, 2016). Private forest sector is a significant component for wood processing sector and state economy. Since 2006 subsidies have been available from the European Agricultural Fund for Rural Development (EAFRD) to private forest owners for the support of forestry activities. Respecting the importance of private forest sector for the entire forest industry, which creates $5.2 \%$ of the total GDP in Latvia (information provided by the Central Statistical Bureau, 2014), the EU support plays an important role in fostering and development of the appropriate private forest sector.

The objective of this study was to investigate the EU legal acts regulating forestry support in member states and coherence to support measures implemented in Latvia for a certain period. The tasks of the research were to identify measures potential available for the development of private forest sector from the EU perspective, and its implementation stage in Latvia's NRDP 2014-2020.

During the elaboration and implementation period of NRDP, several evaluation reports (Benga, 2013, Institute of Agri-Resources and Economy information, 2017) had been prepared, but solely towards achievement of the results or measures already defined or included in NRDP 2014-2020. Taking into account the long cycle of forest development, the efficiency of certain support measures may be evaluated only in long term.

\section{MATERIALS AND METHODS}

Legal acts relevant to the EU support strategy for forestry, at the EU and national level were analysed, focusing on certain priorities and objectives.

Copyright (C) 2017 The Authors. Published by Aleksandras Stulginskis University. This is an open-access article distributed under the terms of the Creative Commons Attribution License (CC-BY 4.0), which permits unrestricted use, distribution, and reproduction in any medium, provided the original author and source are credited. 
EU growth strategy 'EU 2020' (European Commission, 2014), set objectives to be reached by 2020, for smart, sustainable and inclusive economy, some of which are directly binding to forestry sector - to decrease greenhouse gas emissions to $20 \%$, generate $20 \%$ of energy from renewables and increase energy efficiency by $20 \%$. The objective is to use forest stands as Greenhouse Gas (GHG) absorbent and woody biomass as a source for energy production. The strategy appoints EAFRD as most significant EU funding tool directly affecting forest management, implementing it at national level, taking into account national and local circumstances. The goal for the contribution of ERAF to forestry sector focuses on the improvement of competitiveness, protection of the environment, improvement of the quality of life and diversification of the rural economy and supporting of locally based approaches to rural development.

EU Forest Strategy for forests and the forest-based sector, European Commission, 2013, taking into account the assumptions and facts, for harvest rates increase by $30 \%$ by 2020 as compared to 2010, considers forest biomass as most important source of renewable energy and judging the area protected for nature care matters under Natura 2000 (EU network of specially protected areas for nature care) may achieve $\sim 25 \%$ of the EU's total forest area. The guiding principles are sustainable forest management and the multifunctional role of forests, and rural development funds in member states should be used to support the implementation of sustainable forest management, particularly for modernising forestry technologies; optimising the sector's contribution to the bio-economy; improving the resilience, environmental value and mitigation potential of forest ecosystems; achieving nature and biodiversity objectives; favour forest protection and information, support to forest advisory systems for awareness-raising, training, and communication between local forest holders and authorities, and creating new woodland and agro-forestry systems. The European Commission emphasised actions to facilitate forests' mitigation potential through increased removals and reduced emissions, promote forest management practices to limit emissions or increase net biological productivity. The implementation of the above mentioned measures by 2020 should be evaluated toward maintenance and enhancement of forest cover to ensure soil protection, water quality and quantity regulation by integrating sustainable forestry practices, as well as achieving a significant and measurable improvement in the conservation status of forest species and habitats. Forestry measures under the ERAF are the strategy's resource ( $\sim 90 \%$ of the total EU forestry funding), and ERAF spending should be dedicated t contributing to the objectives of the EU Forest Strategy, and in particular to ensuring that the EU forests are demonstrably managed according to sustainable forest management principles.

EU regulation No. 1305/2013 on support for rural development by the EAFRD (European Parliament and Council, 2013). Member states shall develop national regulation to introduce exact measures for supporting rural development, including forest management. Regulation defines several priorities for forestry support - to ensure sustainable development of rural areas; focus on knowledge transfer and innovation, forestry and rural areas; promoting sustainable management of forests. The evolution and specialisation of forestry and the particular challenges faced by micro and small and medium-sized enterprises in rural areas require an appropriate level of technical and economic training as well as an increased capacity to access and exchange knowledge and information including best forestry production practices. Forestry as an integral part of rural development and support for sustainable and climate friendly land use should include forest area development and sustainable management of forests. The measure should cover the extension and improvement of forest resources through the afforestation of land, restoration of forests damaged by fire or other natural disasters and catastrophic events and relevant prevention measures; investments in forestry technologies; the mobilising and marketing of forest products aimed at improving the economic and environmental viability of forest holders; and non- remunerative investments which improve ecosystem and climate resilience and environmental value of forest ecosystems. Support should also be granted to forest holders to help address specific disadvantages in the areas concerned resulting from the implementation of Directive 2009/147/EC and Directive 92/43/EEC and in order to contribute to the effective management of Natura 2000 sites and also for the forest owners who provide environment-friendly or climate-friendly forest conservation services by undertaking commitments to enhance biodiversity and preserve high-value forest ecosystems. Member states should set up and operation of a national rural network that brings together organisations and administrations involved in rural development, including the European Innovation Partnership, with the aim of increasing their involvement in the implementation of the programme and improving the quality of rural development programmes. The following aspects should also be taken into consideration: fostering knowledge transfer and innovation in forestry with a focus on innovation, cooperation; the development of the knowledge base in rural areas; strengthening the links between forestry and research and innovation, including for the purpose of improved environmental management and performance; fostering lifelong learning and vocational training in forestry sectors.

The European Parliament and Council highlight resource efficiency supporting the shift towards a low carbon and climate resilient economy in forestry sectors, with a focus on carbon conservation and sequestration in forestry.

Latvia Rural development programme 2014-2020, (Ministry of Agriculture, Latvia, 2014), included measures and general rules for its implementation at national level for the period 2014-2020.

From the measures included in the EU regulation No. 1305/2013, those measures which are applicable for direct forestry support were divided into four groups: 1) Information, advice, knowledge and efficiency; 2) Forestry activities; 3) Investments in forestry; 4) Nature care, also evaluating national level implementation of certain measure.

\section{RESULTS AND DISCUSSION}

\section{Actions of information, advice, knowledge and efficiency}

EU regulation No. 1305/2013, article 14, knowledge transfer and information actions

Actions of vocational training and acquisition of skills, demonstration and information activities. Actions may include training courses, workshops, coaching and short-term forest management exchanges visits. The EU Parliament 
and Council emphasized particular relevance of this measure to fostering knowledge transfer and innovation in forestry and rural areas. Latvia in its RDP 2014-2020 introduced vocational training for forest owners, entrepreneurs (no. M01), for approximately 1500 persons till the middle of 2018. So far no visits of management exchange have been available, but it may be implemented in the future, because the bound measure is included in Latvia's NRDP 2014-2020. Measure for demonstration activities has not been implemented in Latvia's NRDP 2014-2020.

EU regulation No. 1305/2013, article 15, advisory services, farm management and farm relief services

Consultations to forest holders, to cover at least relevant obligations under Directives 92/43/EEC, 2009/147/EC and the Water Framework Directive. Additionally, consultation actions also may include the economic and environmental issues. The EU Parliament and Council emphasized this measure as particular relevance to several EU priorities.

Latvia in its NRDP 2014-2020 set measures which include consultancy services (no. M02) on forest habitat and wild birds' protection performance and forest management around water objects. Consultations may include economic issues and measure available for private forest owners and small/medium size entrepreneurs. The intended number of participants for the provided consultancy should be as a minimum 200 persons, which may be exceeded, if finances are available for this purpose.

EU regulation No. 1305/2013, article 27, setting -up of producer groups and organisations

Support under this measure intended to facilitate the setting up of producer groups and organisations in the forestry sector, for action of marketing, centralisation of sales and supplies, development of business and marketing skills.

For forest sector measure implemented in Latvia's NRDP 2014-2020 (no. M09), as support for cooperatives of forestry services.

EU regulation No. 1305/2013, article 35, co-operation

Measure to support forms of co-operation involving different forest sector actors to create clusters and networks, European Innovation Partnership groups. For forest sector particularly with the purpose to develop new products, practices, processes, technologies and elaborate forest management plans. The EU Parliament and Council emphasized this measure as particular relevance to several EU priorities. The measure implemented in Latvia's NRDP 2014-2020 (no.M16), may provide support co-operation of forest owners, entrepreneurs, scientists and consultancy entities.

EU regulation No. 1305/2013, article 54, national rural network

Establish and provide functionality for network of stakeholder's organization and administrations active in the field of rural development. The main purpose is to involve stakeholders in rural development and implementation, particularly in forestry, disseminate information on the NRDP measures for potential beneficiaries, and by the way improve quality of national rural development plan. Measure implemented in Latvia's NRDP 2014-2020, network of rural development is founded and provide services for forest owners, forest sector entrepreneurs, hunters and general society.

Actions of Information, advice, knowledge and efficiency as measures are implemented in Latvia, except for demonstration activities. Further estimation of measures introduction in the practical realisation should be accomplished, respecting intended limited amount of realisation.

\section{Forestry activities}

EU regulation No. 1305/2013, article 21, 22, afforestation and creation of woodland

Afforestation of agriculture and non-agricultural land, covering the costs of woodland establishment, maintenance with early and late cleanings. The tree species used must be adapted to the environmental and climatic conditions and the area afforested shall meet the environmental requirements. The EU Parliament and Council emphasized this measure as particularly relevant to preserve and enhance ecosystems dependent of forestry and towards low carbon, climate adapted and efficient economy of forest sector.

Latvia's NRDP 2014-2020 provides support for creation of new woodland or for supplementing established stands on agricultural and non-agricultural land, grown naturally. (no. M08). The support includes also subsequent cleaning of woodland. The expected amount of forest areas created a new till 2020 is estimated to be around 10000 ha. Measure includes relevant restrictions for areas to apply for this activity.

\section{EU regulation No. 1305/2013, article 23, establishment of agroforestry systems}

Support may be granted for land where trees grow in combination with agriculture, covering costs of maintenance for a period of five years, as maximum. The EU Parliament and Council emphasized this measure as particularly relevant to preserve and enhance ecosystems dependent of forestry and towards low carbon, climate adapted and efficient economy of forest sector. Latvia's NRDP 2014-2020 provides support for short rotation tree plantations, as area payments (no.M10).

EU regulation No. 1305/2013, article 24, prevention and restoration of damage to forests from forest fires and natural disasters and catastrophic event

Establishment of protective infrastructure, monitoring facilities, prevention activities against fire, restoring forest potential damaged from fires and other natural disasters including pests.

Latvia's NRDP 2014-2020 provides support for restoring of forest stands, eliminated by impact caused by fire, wind or snow (no. M08). Related state authorities may obtain for support of establishment of fire observation infrastructure.

EU regulation No. 1305/2013, article 25, investments improving the resilience and environmental value of forest ecosystems

Investments intended for actions to achieve environmental aims, for the provision of ecosystem services or improvement of the climate change mitigation potential of forests ecosystems. Support may include economic benefits in 
the long term. EU Parliament and Council emphasized this measure as particular relevant to preserve and enhance ecosystems dependent of forestry and towards low carbon, climate adapted and efficient economy of forest sector.

Latvia's NRDP 2014-2020 includes affordable measures for precommercial thinning of forests stands, including pruning and for the actions to change forest stands of low productivity or not valuable deciduous tree species into forest stands with valuable tree species with a high productivity potential (no. M08).

Actions of Forestry activities as measures are fully implemented in Latvia. Further estimation of the introduction of measures into practice should be accomplished, particularly its impact on conditions in private forest and potential of the climate change mitigation.

\section{Investments in forestry}

EU regulation No. 1305/2013, article 17, investments in physical asset

Foreseen investments for the development, modernisation or adaptation of infrastructure related to forestry, including access to forest land, land consolidation and improvement. Non-productive investments also may be linked to the agri-environment-climate issues, including protection of species and habitats for biodiversity purposes, improvement of a Natura 2000 or other high nature value area. The EU Parliament and Council emphasized this measure as particular relevance to several EU priorities. Latvia in its NRDP 2014-2020 set measures for investment in the forest melioration system improvement (no. M04). The measure is introduced as joint activity for agricultural and forest lands, but not fixed amount is set of financial resources to be dedicated for forest lands. Implementation requires relevant investment from beneficiary and mostly intended for medium and large amount projects.

EU regulation No. 1305/2013, article 26, investments in forestry technologies, processing, mobilising and in the marketing of forest products

Investments foreseen under the above mentioned measure are to enhance forestry potential or to process, mobilise and market forest products. These investments may include soil-friendly and resource -friendly harvesting machinery and practices. The EU Parliament and Council emphasized particular relevance of this measure to fostering knowledge transfer and innovation in forestry and rural areas. The measure has not been implemented in Latvia's NRDP 2014-2020.

Actions of Investments in forestry as measures are partly implemented in Latvia. Further estimation of the introduction of measures into practice should be accomplished, taking into account the intended limited amount of implementation.

\section{Nature care}

EU regulation No. 1305/2013, article 30, Natura 2000 and Water Framework Directive payments

Measure to compensate forest owners additional costs and income foregone on areas due implementation of Directives 92/43/EEC and Directive 2009/147/EC and the Water Framework Directive. Support available annually per hectare of forest, and area applicable for this measure may be extended outside Directive scope (Natura 2000 areas), including forests contributing the implementation of Directives, but in limited amount. The EU Parliament and Council emphasized this measure as particularly relevant to preserve and enhance ecosystems dependent of forestry and towards low carbon, climate adapted and efficient economy of forest sector. Latvia's NRDP 2014-2020 provides compensative payments for forest holdings in the Natura 2000 areas and in limited amount also outside those areas (no.M12). The amount of compensation is strictly related to the rate of management restriction and as average expected profit per year for all tree species.

EU regulation No. 1305/2013, article 34, forest-environmental and climate services and forest conservation

Available support for public and private forest owners to implement actions for environment and climate commitments. Actions should be undertaken on voluntary basis and they shall exceed mandatory obligation laid down by national forest act or other legal acts. Payments should be granted per hectare, for certain period, minimum for five years, to compensate additional costs and income foregone. The EU Parliament and Council emphasized this measure as particularly relevant to preserve and enhance ecosystems dependent on forestry and towards low carbon, climate adapted and efficient economy of forest sector. Measure has not been implemented in Latvia's NRDP 2014-2020.

Actions of Nature care as measures are partly implemented in Latvia. Further estimation of the introduction measures into practice should be accomplished, their impact on preserving and protecting biodiversity in private forests.

With regard to the approved the NRDP 2014-2020, Latvia as an EU member state included significant measures intended for the support of private forest sector. The measures from the group Forestry activities are most confidently represented in the NRDP 23014-2020, where Latvia implemented all the available activities laid down by the EU. These measures meet also high demands from private forest owners due to simple implementation, suitable rate of finance and covering regular forest management activities. Latvia implemented almost all available activities laid down by the EU regarding the group of measures Actions of information, advice, knowledge and efficiency. Several activities were introduced for the first time in Latvia, however, the intended amount of beneficiaries is small versus total number of private forest owners. Actions do not provide direct financial benefit for forest owners and that might conclude in low interest from forest owners to implement these measures. The measures of group Investments in forestry are represented only by one case in the NRDP 2014-2020 - support for the forest melioration system improvement. However, also implementation conditions of this activity cause a situation, that the activity is mostly suitable for large forest owners and entrepreneurs. Thereby to some extend the scope of particular relevance laid down by the EU Parliament and Council is not implemented in Latvia. The implementation measures of group Nature care, cover mandatory obligations for forest owners regarding nature protection, not providing support for voluntary commitments, that has been emphasised as relevant by the EU Parliament and Council. 


\section{REFERENCES}

1. Benga, E. 2013. Ex-ante evaluation report for Rural development programme 2014-2020. Available at https://www.zm.gov.lv/public/files/CMS_Static_Page_Doc/00/00/00/39/80/Ex_ante_gala_2014.pdf.

2. Donis, J. Latvian Forest Research Institute Silava, Monitoring of private forest management, holding consolidation and cooperation. Available at https://www.zm.gov.lv/public/ck/files/MAF2016priv_v2ofic.pdf.

3. Europe 2020 strategy, Available at https://ec.europa.eu/info/business-economy-euro/economic-and-fiscal-policy-coordination/eueconomic-governance-monitoring-prevention-correction/european-semester/framework/europe-2020-strategy_en.

4. EU Forest Strategy: for forests and the forest-based sector. Available at http://eur-lex.europa.eu/legalcontent/EN/TXT/HTML/?uri=CELEX:52013DC0659\&from=EN.

5. Latvia Rural development programme (national), 2014-2020. Available at https://www.zm.gov.lv/lauku-attistiba/statiskaslapas/2014-2020-gada-planosanas-periods-/latvijas-lauku-attistibas-programma-2014-2020-gadam-?nid=2191\#jump.

6. Regulation (EU) No 1305/2013 of the European Parliament and of the Council of 17 december 2013 on support for rural development by the European Agricultural Fund for Rural Development (EAFRD) and repealing Council Regulation (EC) No 1698/2005, 2013 Official Journal of the European Union. 